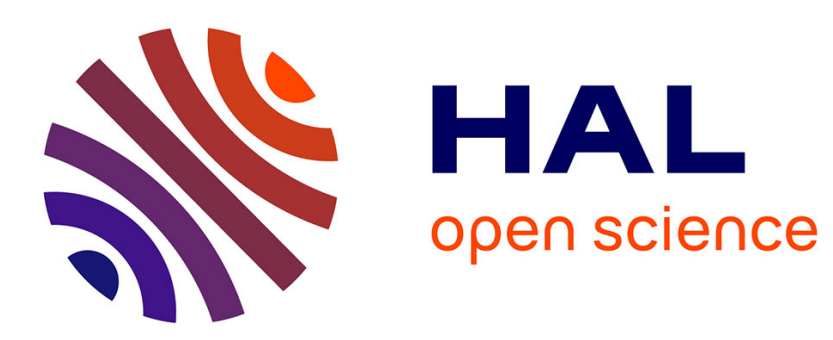

\title{
Reply to Matisoff on the Handbook of Proto-Tibeto-Burman: System and philosophy of Sino-Tibetan reconstruction \\ Laurent Sagart
}

\section{- To cite this version:}

Laurent Sagart. Reply to Matisoff on the Handbook of Proto-Tibeto-Burman: System and philosophy of Sino-Tibetan reconstruction. Diachronica, 2008, 25 (1), pp.153-155. 10.1075/dia.25.1.13.sag . hal00780992

\section{HAL Id: hal-00780992 \\ https://hal.science/hal-00780992}

Submitted on 25 Jan 2013

HAL is a multi-disciplinary open access archive for the deposit and dissemination of scientific research documents, whether they are published or not. The documents may come from teaching and research institutions in France or abroad, or from public or private research centers.
L'archive ouverte pluridisciplinaire HAL, est destinée au dépôt et à la diffusion de documents scientifiques de niveau recherche, publiés ou non, émanant des établissements d'enseignement et de recherche français ou étrangers, des laboratoires publics ou privés. 
Reply to Matisoff on the Handbook of Proto-Tibeto-Burman: System and philosophy of SinoTibetan reconstruction

\section{Laurent Sagart (Centre National de la Recherche Scientifique, Paris)}

In my review of the Handbook of Proto-Tibeto-Burman [Diachronica 23.1:206-223], I called its treatment of TB rhymes "a most welcome advance" and "a noteworthy achievement". In his response [Diachronica 24.2:435-444] to that review, James Matisoff (henceforth M) takes exception to the following, more critical points: the lack of explicitness in the reconstruction of TB consonantal onsets, his approach to subgrouping, and his use of Karlgren's outdated Chinese reconstruction. He also points to my past lack in judgment concerning the nature of the Chinese/TB relationship.

Hypotheses are made to be tested, and to be abandoned in favor of better ones when they fail. Around 1990, I shared Meillet's distrust of the value of the lexicon in establishing genetic relationships. ST as argued for in Benedict's Conspectus relied more on the basic character of proposed cognates than on explicitly formulated sound correspondences or morphological agreements. When I made the unexpected discovery of sound correspondences between Chinese and Austronesian words (including one between $\mathrm{AN}^{*}$-q and $\mathrm{OC} *_{-}$, , the source of the marked member among the two basic Chinese tones), I proposed that Chinese was more closely related to $\mathrm{AN}$ than to TB and that the bulk of the proposed TB/OC vocabulary consisted of Chinese loanwords into Proto-TB (not implausible a priori: Chinese has loaned huge sets of words to other languages in contact with it, like Hmong-Mien and Tai-Kadai). My hypothesis made two testable predictions: first, that secure Chinese loans could be found in all TB languages, regardless of geographical location; and second, that Chinese morphology (then still poorly understood) would be closer to AN morphology than to TB morphology. In the nineties I embarked on two research programs to test them. Regarding the first, I found Chinese loanwords in the TB languages in contact with Chinese like Burmese, Bai, Hani, but not elsewhere. Regarding the second, I worked out an internal reconstruction of OC morphology (Sagart 1999) which turned out to be very close to TB morphology. At the same time, after limiting AN material to Formosan languages, phonological, morphological and lexical evidence started appearing which linked both TB and OC equally tightly to AN. These results falsified my old hypothesis. I accordingly abandoned it, and accepted ST as a taxon. I also accepted that Benedict was right on the value of the basic vocabulary, and proposed that all of ST is coordinate with AN within a macrophylum I call "Sino-TibetanAustronesian" (Sagart 2005). Is it a disgrace to argue in favor of a theory and abandon it if, after testing it, you find it wrong?

I observed that $\mathrm{M}$ reconstructs initial consonants without stating the correspondences that support them. As a result it is very difficult to know what constitutes counterevidence to these reconstructions. Lack of explicitly stated correspondences and correspondence tables also hides the fact that some of the reconstructed consonants are without reflex in some of the principal languages (as with M's *w in Tibetan). These gaps, which should alert other scholars to problematic areas in the system, are not pointed out. If for whatever reason it is difficult or impossible to reconstruct initial consonants for $\mathrm{TB}$, then either they should not be reconstructed, or it should at least be explained how they are reconstructed.

I also pointed out the unconstrained use of pseudo-affixes in assembling TB cognates. As an example of this, consider M's response to my suggestion that Tibetan g-is the missing reflex to his ${ }^{*} \mathrm{w}-$, illustrated with four examples of words having Tibetan g- and Burmese w-. Of these, $\mathrm{M}$ accepted one ("tuber") and another tentatively ("to go"), but countered that they are examples of his *grw-, where Burmese has "treated g and $\mathrm{r}$ as prefixes" (understand: has lost $\mathrm{g}$ - and -r- as a result of untold, random processes), so that only w- remains. 
Or consider our exchange on his *kla $\sim$ gla "to fall", a root allegedly occurring with and without his "semantically elusive" suffix -k. I argued the forms cited really needed two distinct roots, both represented in Chinese, one ending in $-\mathrm{k}$ (not a suffix), the other without. In his reply M cited yet other TB forms consisting of his *kla gla plus "suffixed" -t and -y, without offering evidence of their suffixal nature. The possibility at least needs to be considered that these forms are not cognate.

$\mathrm{M}$ argues the time is not ripe for a secure TB phylogeny - the time depth is too great, as in IE. And yet at an even deeper time depth, he is certain that ST has precisely two branches, Chinese vs. TB. When pressed to explain why, he cautiously asserts that "the fact that [Chinese] is not verb-final should count for something" (fn. 5). But if Chinese innovated VO order, that change could have occurred regardless of the position of Chinese in ST. Or is M actually saying that $\mathrm{OV}$ order is an innovation of TB? ${ }^{1}$

Finally, regarding M's choice of Karlgren's OC reconstruction, one should keep in mind that Karlgren's system lacks many distinctions uncovered by later scholarship: Karlgren's reconstructions cannot be converted into more recent systems.

\section{References}

Djamouri, Redouane, Waltraud Paul \& John Whitman. 2007. "Reconstructing VO constituent order for proto-Sino-Tibetan". Paper presented at The 18th International Conference on Historical Linguistics. Université du Quebec à Montréal.

Sagart, Laurent. 1999. The Roots of Old Chinese [= Current Issues in Linguistic Theory, 184.] Amsterdam: John Benjamins.

Sagart, Laurent. 2005. "Sino-Tibetan-Austronesian: An updated and improved argument". In The Peopling of East Asia: Putting together archaeology, linguistics and genetics ed. by Laurent Sagart, Roger Blench \& Alicia Sanchez-Mazas, 161-176. London: Routledge Curzon.

\section{Discussant's address}

Laurent Sagart

Centre de Recherches Linguistiques sur l'Asie Orientale

EHESS, 54 bd Raspail

75270 Paris, France

E-mail: laurent.sagart@gmail.com

1 This was convincingly argued by Djamouri, Paul \& Whitman (2007). However the subgrouping value of word order is weak: TB languages could easily have shifted to OV independently, through areal contact with IE or Altaic. 